\title{
TRADE OPENNESS AND ECONOMIC GROWTH: EMPIRICAL EVIDENCE FROM INDIA
}

\author{
Qazi Muhammad Adnan HYE ${ }^{1}$, Wee-Yeap LAU ${ }^{2}$ \\ ${ }^{1}$ Department of Economics, Faculty of Economics and Administration, \\ University of Malaya, 50603 Kuala Lumpur, Malaysia \\ ${ }^{2}$ Department of Applied Statistics, Faculty of Economics and Administration, \\ University of Malaya, 50603 Kuala Lumpur, Malaysia \\ E-mails: ${ }^{1}$ adnan.economist@yahoo.com; ${ }^{2} w y l a u @ u m . e d u . m y$ (correspondingauthor) \\ Received 04 July 2011; accepted 06 August 2012
}

\begin{abstract}
The main objective of this study is to develop first time trade openness index and use this index to examine the link between trade openness and economic growth in case of India. This study employs a new endogenous growth model for theoretical support, auto-regressive distributive lag model and rolling window regression method in order to determine long run and short run association between trade openness and economic growth. Further granger causality test is used to determine the long run and short run causal direction. The results reveal that human capital and physical capital are positively related to economic growth in the long run. On the other hand, trade openness index negatively impacts on economic growth in the long run. The new evidence is provided by the rolling window regression results i.e. the impact of trade openness index on economic growth is not stable throughout the sample. In the short run trade openness index is positively related to economic growth. The result of granger causality test confirms the validity of trade openness-led growth and human capital-led growth hypothesis in the short run and long run.
\end{abstract}

Keywords: trade openness, human capital, economic growth, ARDL, Ng-Perron, India.

JEL Classification: F13, O4.

\section{Introduction}

The theoretical literature indicates that trade openness plays a vital role in the process of economic growth in the developing countries. The trade openness is a key element of academic and policy musing for a several reasons. First, the trade openness is an important part of the structural adjustment program that was supported by the World Bank and International Monetary Fund in various developing countries. Second, many empirical studies are suggested the importance of trade openness in economic growth through exports-led growth hypothesis and import-led growth hypothesis (see Balassa 1985; Ram 1987; Bhagwati 1978; Greenaway, Nam 1988; Salvatore, Hatcher 1992; Awokuse 2007, 2008; Mishra et al. 2010; Hye, Boubaker 2011; Shahbaz et al. 2011; 
Nasreen 2011). Third, the stories of flourishing economic growth (of East Asian countries) convey the importance of trade openness policies. Last, the development of endogenous (new) growth theories offers a theoretical basis for empirical investigation of the association between trade openness and economic growth. In contrast the neo-classical growth theory recognizes no association between trade openness and economic growth. It shows that the economic growth is exogenously defined by the technology, which proposes that long term economic growth cannot cause by the interaction with other countries. But the new growth theories indicate that trade openness increases economic growth by enhancing the scale of spillover (Romer 1990).

This study is motivated because India opens her foreign trade management in order to sustain economic growth. These policy reforms are as follows: the exchange rate was liberalized in March 1, 1992. The five years (1992-1997) export-import policy was launched in 1992. According to this policy the export was required to capitulate 40 per cent of foreign exchange receiving at the official market exchange rate. With the help of this amount the government imports the necessary things: for example petroleum, fertilizers and life saving drugs. The remaining 60 percent the foreign exchange earnings could use to import of raw material. Alongside liberalize exchange rate system; the old import license system was replaced with the tariff system: now the importers could import capital and intermediate commodities simply the payment of tariff. The import duty on the capital goods was reduced from $25 \%$ to $15 \%$ (CMIE 2000) ${ }^{1}$. All quantitative restriction on imports (2300 items) from SAARC nations were removed in August 1, 1998. The main aim of this reform is to promote trade between SAARC countries (Ministry of Finance). The tariff rate in the country is reduced from 79.1 percent in 1990-1991 to 30 percent in 2001.

But the theoretical literature shows that a different group of models in which trade openness can expedite or impede the international economic growth (see Rivera-Batiz, Romer 1991), if trading allies have significantly different in factor endowments, then if economic integration increases the global economic growth, it's possible will be a negative influenced on individual countries (see Rivera-Batiz, Xie 1993; Young 1991; Kind 2002). There are few empirical studies that providing the evidence of a negative relationship between the trade openness and economic growth like Vamvakidis (2002), Kim (2011) and Hye (2012). With this background in mind, there is vital to explore the link between trade openness and economic growth in case of India. Thus this paper aims to examine the effects of trade openness on economic growth in India over 1971-2009. As a contribution to the literature on the subject, this paper constructs the composite trade openness index by using various proxies of trade openness, i.e. import divided by GDP, export divided by GDP, and export plus import divided by GDP. It employs the new endogenous growth by including trade openness index in this model. For estimation evidence it employs the relative new cointegration techniques like Autoregressive Distributed Lag (ARDL) approach to cointegration (Pesaran et al. 2001) and rolling window regression method. The ARDL method has the following advantages over the other cointegration techniques. First it can apply irrespective the regressors are integrated order one or order zero or mutually (Pesaran et al. 2001). Second a dynamic error correction model (ECM) can

\footnotetext{
${ }^{1}$ The importer will pay lower duty if he agrees to achieve a specific target of export.
} 
be derived from ARDL through a simple linear transformation. The last ARDL model is free from serial correlation and endogeneity problems. The remaining article is structured as follows: section 1 defines review of the literature; section 2 explains estimation techniques; section 3 shows the results and interpretations section 4 gives the conclusion.

\section{Review of the literature}

The theoretical literature shows the impact of trade openness on economic growth by different channels that are increasing in capital accumulation, factor price equalization and knowledge spillovers. Rivera-Batiz (1995) stated various channels by which trade openness impacts on economic growth. The first is the re-allocation effect on economic growth because trade openness can increase the quantity of human capital in the leading industries. The second trade openness is causing the spillover effect of the transmission of knowledge across the countries. According to this explanation trade openness increases flow of technological knowledge across countries, and this has a positive impact on long-run economic growth. Rivera-Batiz also explained if the domestic human capital system is not able to grip efficiently the innovative knowledge that generates by trade openness, then trade openness is negatively related to economic growth. The third type of effect has described the competition effect that is associated with the issue of imitation or replication. Which is the developed economy innovates and less developed economy imitates (Grossman, Helpman 1991).

On the other hand, trade empirical literature shows that the number of researchers investigates the effectiveness of trade openness by using the data of cross country, panel and individual country case. The cross country and panel studies are included: Romer (1989) examined the trade openness and economic growth nexus by using the data of 90 developing countries. He suggests that trade openness is helping to get a wider array of innovations. Further the trade openness and human capital accumulation positively causes to economic growth that confirmed by Villanueva (1994)2. Edward (1992) used two types of trade openness indicators, i.e. trades intervention and distortions in the case of 30 developing countries. He constructs two indicators of trade openness by using the methodology Leamer (1988) and found openness indicator is positive and trade intervention indicator is negatively associated with economic growth. He recommends on the basis of empirical results that those countries are following trade openness policies is growing faster as compare to close trade regime. McNab and Moore (1998) use the data of 41 countries developing countries ${ }^{3}$ and found that a strong outward trade

\footnotetext{
${ }^{2}$ By using the data of 36 countries. The list of countries as follows: Botswana, Islamic Republic of Iran, Burkina Faso, Kenya, Cameroon, Korea, Chile, Liberia, Costa Rica, Mauritius, Dominican, Republic, Mexico, Egypt, Morocco, El Salvador, Ldyanmar, Ethiopia, Nepal, Fiji, Pakistan, Guatemala, Panama, Indonesia, Paraguay, Singapore, Sri Lanka, Tanzania, Thailand, Togo, Tunisia, Turkey, Uruguay, Venezuela, Yemen, Arab Republic, Zambia, Zimbabwe.

${ }^{3}$ Argentina, Bangladesh, Bolivia, Brazil, Burundi, Cameroon, Chile, Colombia, Costa-Rica, Coted'Ivoire, Dominican Republic, El-Salvador, Ethiopia, Ghana, Guatemala, Honduras, Hong Kong, Indonesia, India, Israel, Kenya, Madagascar, Malaysia, Mexico, Nicaragua, Nigeria, Pakistan, Peru, Philippines, Senegal, Singapore, South-Korea, Sri Lanka, Sudan, Tanzania, Thailand, Tunisia, Turkey, Uruguay, Yugoslavia, Zambia.
} 
policy has increased annual GDP growth (on average) over 3 per cent, while a moderately outward trade policy has increased annual GDP growth over 1.6 per cent, and the grnager causality test shows the bidirectal relationship between export and economic growth. Wacziarg (2001) examined the link between trade policy and GDP growth in the case of 57 countries $^{4}$. He used three trade policy indicators, i.e. tariff barrier, non-tariff barriers and a dummy variable is included in the model for trade liberalization status. He concludes positive link among trade openness and GDP growth. Ynikkaya (2003) employed the data of 120 countries $^{5}$ and investigate the impact of trade openness on per capita income growth. In analysis the two trade openness measures are employed: first trade volumes (export, import, export plus import) as a percentage of GDP, and the second trade restrictiveness on foreign exchange of bilateral payments and current transactions. His empirical results indicate that trade volume and trade restriction both are positively associated with economic growth. Söderbom and Teal (2001) suggest that trade openness is positively impacted and while human capital does not effect on the rate of growth of productivity by using the data of 54 countries $^{6}$. But Isaksson (2002) concluded that human capital is an important element in the trade-growth link by using the data of 73 developed and developing countries ${ }^{7}$. Further human capital and trade

\footnotetext{
${ }^{4}$ Australia, Austria, Belgium, Canada, Finland France, Germany-west, Greece, Ireland, Italy, Japan, Netherland, New Zealand, Norway, Portugal, Spain, Sweden, Switzerland, Turkey, United States, United Kingdom, Cyprus, India, Israel, Jordan, Malaysia, Myanmar, Pakistan, Philippines, Singapore, Srilanka, Syria, Thailand, Argentina, Barbados, Brazil, Colombia, Costa Rica, Dominican Republic, El Salvador, Guyana, Mexico, Paraguay, Peru, Venezuela R.B.de, Congo Dem. Rep, Ghana, Kenya, Malawi, Mauritius, Sierra Leone, South Africa, Tanzania, Gambia, Tunisia, Zambia.

${ }^{5}$ Argentina, Australia, Austria, Bahamas, Bangladesh, Barbados, Belgium ,Benin, Bolivia ,Botswana, Brazil, Burundi, Cameroon, Canada, Central African Republic, Chile, China, Colombia, Comoros, Costa Rica, Cote d'Ivoire, Cyprus, Denmark, Dominican Republic, Ecuador, Egypt, Arab Rep, El Salvador, Ethiopia, Fiji, Finland France, Gabon, Gambia The, Germany, Ghana, Greece, Guatemala, Guinea, Guinea-Bissau, Guyana, Haiti, Honduras, Hungary, Iceland, India, Ireland, Israel, Italy, Jamaica, Japan, Jordan, Kenya, Korea Rep, Lesotho, Luxembourg, Madagascar, Malawi, Malaysia, Mali, Malta, Mauritania, Mauritius, Mexico, Morocco, Myanmar, Nepal, Netherlands, New Zealand, Nicaragua, Niger, Norway, Oman, Pakistan, Panama, Papua New Guinea, Paraguay, Peru, Philippines, Poland, Portugal, Romania, Rwanda, Senegal, Sierra Leone, Singapore, Somalia, South Africa, Spain, Sri Lanka, Sudan, Suriname, Swaziland, Sweden, Switzerland, Syrian Arab Republic, Tanzania, Thailand.

${ }^{6}$ Argentina, Australia, Austria, Belgium, Bolivia, Canada, Chile, Colombia, Denmark, Dominican Republic, Ecuador, Finland, France, Greece, Guatemala, Honduras, Hong Kong, Iran, India, Iceland, Ireland, Israel, Italy, Japan, Jamaica, Kenya, Malawi, Mauritius, Mexico, Netherlands, New Zealand, Norway, Panama, Paraguay, Peru, Philippines, Portugal, Republic of Korea, Sierra Leone, Spain, Sri Lanka, Syria, Sweden, Swtizerland, Taiwan, Thailand, Turkey, U.K, U.S.A, Venezuela, West Germany, Yugoslavia, Zambia, Zimbabwe.

${ }^{7}$ Argentina, Australia, Austria, Belgium, Bolivia, Brazil, Canada, Central, African Republic, Cameroon, Chile, Colombia, Congo, Costa Rica, Cyprus, Dem Rep. of Congo, Denmark, Dominican Republic, Ecuador, Egypt, Finland, France, Gambia, Ghana, Great Britain, Greece, Guatemala, Haiti, Honduras, India, Indonesia, Iran, Ireland, Israel, Italy, Japan, Jamaica, Kenya, Korea, Lesotho, Malawi, Malaysia, Malta, Mauritius, Mexico, Nepal, Netherlands, New Zeeland, Nicaragua, Niger, Norway, Pakistan, Papua New Guinea, Paraguay, Peru, Philippines, Portugal, Rwanda, Senegal, Slovakia, South Africa, Spain, Sri Lanka, Sweden, Switzerland, Sudan, Syria, Thailand, Togo, Trinidad, Tobago, Uruguay, USA, Venezuela, Zimbabwe.
} 
openness are contributed to the economic growth in both developing and developed ${ }^{8}$ countries at different rates (Sonmez, Sener 2009). Recently Soukiazis and Antunes (2012) use the data of 14 EU countries ${ }^{9}$, and conclude that human capital, external trade and their interaction terms between them have significant effects on economic growth.

Ghatak et al. (1995) conclude a stable long run relationship between the trade liberalization, human capital, physical capital and economic growth in case of Turkey by using the cointegration method. Further the impact of trade openness and foreign technology on economic growth is not stable; where as impact of education on economic growth is positive and stable in case of Argentina (Véganzonès et al. 1998). Chuang (2000) used cointegration and error correction model in case of Taiwan by using sample size 1952-1995. He founds human capital accumulation foster growth and exports, although exports endorse long-run growth by increasing the process of human capital accumulation, and thus suggests human capital-based endogenous growth theory, and the exportled growth hypothesis is valid.

Ahmad (2003) used an endogenous growth model to investigate the relationship between trade openness and industrial sector growth in case of Bangladesh. He found a long run relationship between industrial production, investment and trade openness (export divided by GDP). In same way the positive relationship between trade openness and industrial sector growth is found by Dutta and Ahmed (2004) in case of Pakistan. The study of Carmen and Pilar (2004) examines the impact of manufacturing sector import on real GDP and employment in case of china by using quarterly data of 1979-2002. They conclude long run relationship between trade openness and economic growth. Kingsley et al. (2006) examine the association between trade openness and economic growth in case of Nigeria by employing the Vector Auto regression method. They found a long run relationship between trade and growth, and suggested that growth could sustain by applying a broad trade openness reforms in Nigeria.

In case of India, Topalova (2004) found that trade liberalization enhances the firm's productivity, and thus productivity leads to the improvement in economic welfare of India. Barua et al. (2006) investigate the relationship between trade liberalization and industrial sector performance in India. They conclude trade liberalization causes to high price margins, reduce the industrial concentration, increases consumer surplus by reducing the producer surplus. Vedpal et al. (2007) examine the relationship between trade openness and economic growth in the case of India by using the real import, export, and import plus export as an indicator of trade openness. They found bidirectional causality among economic growth and trade openness indicators, and recommends a higher level of trade openness enhances the economic growth. Dash (2009) tested export-led growth hypoth-

\footnotetext{
${ }^{8}$ Developing countries: Argentina, Brazil, Bulgaria, Czech Republic, Hungary, Mexico, Poland, South Africa, South Korea and Turkey. Developed countries: Austria, France, Germany, Italy, Japan, Netherlands, Norway, Switzerland, Spain and U.K.

${ }^{9}$ Austria, Belgium, Denmark, Finland, France, Germany, Greece, Ireland, Netherlands, Portugal, Spain, Sweden, U.K.
} 
esis in India by using the data 1991-Q1 to 2007-Q4. He found a long run relationship among export and output, and unidirectional causality from export to economic growth. He recommends further trade openness in order to sustain the long economic growth. Marelli et al. (2011) use the 2SLS, Fixed Effects, Instrumental Variable Approach in the case of China and India to analysis the association between economic growth and trade openness. They show the positive impact of trade openness on economic growth.

In contrast few theoretical and empirical studies are stated that trade openness impedes economic growth. Batra and Slottje (1993) indicate that trade liberalization is associated with an increase in poverty, which is against the theory. Kind (2002) merged the new trade theory and endogenous growth models, and argues that there are ambiguous effects of trade liberalization on economic growth among countries due to difference in size of their home markets. Moreover specially the trade liberalization in low purchasing power countries can reduce the $R \& D$ incentive as compared to high purchasing power countries. The study also thinks the case of imperfect international knowledge spillovers, and explains that full trade liberalization can negatively causes to rate of economic growth. Kim (2011) used the data of 61 countries $^{10}$, and finds that greater trade openness is positively related to economic growth and real income in case of develop countries but it is negatively linked to economic growth in case of developing countries. Hye (2012) employed JJ cointegration, autoregressive distributed lag (ARDL) approach to cointegration, dynamic OLS, variance decomposition, and principal component analysis (PCA) in case of Pakistan to test the link between trade openness and economic growth. His empirical results indicate a negative association between trade openness and economic growth ${ }^{11}$.

\section{Estimation techniques}

The relationship between trade openness and economic growth is modeled by using the new endogenous growth theory. The new endogenous growth models are considered that the human capital accumulation through schooling as an engine of economic growth. The endogenous growth models are grouped in two main streams: first is closed to neoclassical perception and gives importance to the capital accumulation (physical and human capital) that is not subject to decreasing returns (Lucas 1988; Mankiw et al. 1992). The second emphasizes the endogenous growth of $R \& D$ as

\footnotetext{
${ }^{10}$ Argentina, Australia, Austria, Belgium, Bolivia, Brazi, Canada, Chile, Colombia, Costa Rica, Cyprus, Denmark, Dominican, Ecuador, El Salvador, Finland, France, Germany, Ghana, Greece, Guatemala, Guyana, Haiti, Honduras, Iceland, India, Ireland, Israel, Italy, Japan, Jamaica, Kenya, Korea, Malaysia, Malta, Mauritius, Mexico, New Zealand, Netherlands, Niger, Norway, Paraguay, Pakistan, Panama, Papua New Guinea, Peru, Philippines, Portugal, Republic, Senegal, South Africa, Spain, Sri Lanka, Sweden, Switzerland, Togo, Trinidad, Tobago, United Kingdom, United States, Uruguay, Venezuela, Zimbabwe.

${ }^{11}$ On the other hand this study provides an evidence of a strong complementary link between human capital and trade openness index in terms of enhancing the real GDP in the long run.
} 
the vital part of economic growth (Aghion, Howitt 1998; Turnvosky 2001). In less developed countries, human capital is a vital source for the understanding of new technologies that advanced by developed countries. In this framework, human capital is a fundamental factor in the developing countries to benefit from foreign technology (Abramovitz 1986; Benhabib, Spiegel 2003). The new endogenous growth model is written as follows:

$$
Y_{t}=A_{t} K_{t}^{\beta}\left(\mu q_{t} L_{t}\right)^{1-\beta} q_{\alpha}^{\delta}
$$

where $Y_{t}$ is the total output; $A_{t}$ is the level of technology (assumed to be constant); $K_{t}$ and $L_{t}$ respectively physical capital and total numbers of workers. The is average quality of human capital and $q_{\alpha}^{\delta}$ shows the externalities of average human capital. Lucas (1988) has assumed that all labor force is same skill level $\left(q_{t}=q_{\alpha}\right)$. The model should be as follows:

$$
Y_{t}=A_{t} K_{t}^{\beta}\left(\mu L_{t}\right)^{1-\beta} q_{t}^{1+\delta-\beta}
$$

The Lucas has stated stable positive economic growth due to the increasing returns to scale $(2+\delta-\beta>2-\beta>1)$. The stable economic growth depends on the value of $\delta$. For simplicity Lucas has supposed that the workers use a fraction $(\mu)$ of their nonleisure time to current production, dedicating the remaining $(1-\mu)$ to human capital accumulation thus:

$$
\Delta q_{i} / q_{i}=\gamma_{i} \mu_{i}
$$

where $\gamma_{i}$ denotes the positive coefficient which is representing workers' skill formation in sector $i$. The internal and external skill of workers is enhanced under the trade openness. This empirical work examines the relationship between trade openness and economic growth by using the Lucas production model, in which the trade openness is used as a separate factor input with the other input factor like physical capital and human capital:

$$
Y=F(S L, K, T O I)
$$

We rewrite function 3 in equation as follows:

$$
\operatorname{Ln}(Y)=\theta_{0}+\theta_{1} \operatorname{Ln}(S L)+\theta_{2} \operatorname{Ln}(K)+\theta_{3} \operatorname{Ln}(T O I)+\varepsilon_{i},
$$

where $Y, S L, K$ and TOI respectively confers the real GDP, skill labor force/ human capital, physical capital and trade openness index. The shows the sign of natural logarithm, and are representing the slope coefficients of respective variables. The is the error correction terms. 
To examine the long run relationship this study employs Autoregressive Distributed Lag (ARDL) approach. This approach has developed by Pesaran et al. (2001). The Pesaran et al. method of cointegration is involved with estimating the following error correction model:

$$
\begin{aligned}
\Delta \operatorname{Ln}(Y)_{t}= & \lambda_{0}+\sum_{i=1}^{\rho} \lambda_{i} \Delta \operatorname{Ln}(Y)_{t-i}+\sum_{i=0}^{\rho} \lambda_{i} \Delta \operatorname{Ln}(S L)_{t-i}+\sum_{i=0}^{\rho} \lambda_{i} \Delta \operatorname{Ln}(K)_{t-i} \\
& +\sum_{i=0}^{\rho} \lambda_{i} \Delta \operatorname{Ln}(T O I)_{t-i}+\alpha_{1} \operatorname{Ln}(Y)_{t-1}+\alpha_{2} \operatorname{Ln}(S L)_{t-1}+\alpha_{3} \operatorname{Ln}(K)_{t-1} \\
& +\alpha_{4} \operatorname{Ln}(T O I)_{t-1}+\psi_{t},
\end{aligned}
$$

where $\Delta$ is the difference operator, indicates the optimum lag and $\psi_{t}$ is the error term. The existence of long-run relationship among the variables is tested by using overall F-test statistic and t-statistic. The no-cointegration null hypothesis of F-statistic for equation (5) is that $\left\langle H_{0}=\alpha_{1}=\alpha_{2}=\alpha_{3}=\alpha_{4}=0\right\rangle$, the alternative hypothesis of cointegration is $\left\langle H_{0}=\alpha_{1}=\alpha_{2}=\alpha_{3}=\alpha_{4} \neq 0\right\rangle$. The decision of long run relationship is taken in this way: if the computed F- test has exceeded the upper critical bound value, then the $H_{0}$ (null hypothesis) is rejected and if the F- test statistic falls into the bounds, then the test becomes inconclusive. Lastly, if the F-test statistic is below the lower critical bounds value, it implies no co-integration. On the other hand the T-statistic is tested through $\alpha_{1}=0$ in Eq. (5). When a long-run relationship exists then in next step we estimate the long run and short coefficient coefficients.

After that next we perform standard modify Granger causality test which is augmented with a lagged error-correction term. The granger representation theorem suggests that there will be granger causality in at least one direction if there exist a co-integration relationship among the variables in equations (5) by providing that they are integrated order one. Engle-Granger (1987) present simple granger causality test, which is based on first difference via a vector auto-regression (VAR), it will be misleading in the presence of co-integration. Therefore, an inclusion of an additional variable in the VAR system, such as the error-correction term, would help us to capture the long-run causal direction. To this end, an augmented form of granger causality test involving the errorcorrection term is formulated in a multivariate $\rho$ th order vector error-correction model (VECM), as follows:

$$
\left[\begin{array}{l}
\Delta Y_{t} \\
\Delta S L_{t} \\
\Delta K_{t} \\
\Delta T O I_{t}
\end{array}\right]=\left[\begin{array}{l}
\varsigma_{1} \\
\varsigma_{2} \\
\varsigma_{3} \\
\varsigma_{4}
\end{array}\right]+\sum_{i=1}^{\rho}\left[\begin{array}{lll}
n_{11 i} & n_{12 i} & n_{13 i} \\
n_{21 i} & n_{22 i} & n_{23 i} \\
n_{31 i} & n_{32 i} & n_{33 i} \\
n_{41 i} & n_{42 i} & n_{43 i}
\end{array}\right]\left[\begin{array}{l}
\Delta \ln Y_{t-i} \\
\Delta \ln S L_{t-i} \\
\Delta \ln K_{t-i} \\
\Delta \ln T O I_{t-i}
\end{array}\right]+\left[\begin{array}{l}
\lambda_{1} \\
\lambda_{2} \\
\lambda_{3} \\
\lambda_{4}
\end{array}\right]\left[E C_{t-1}\right]+\left[\begin{array}{l}
\varpi_{1} \\
\varpi_{2} \\
\varpi_{3} \\
\varpi_{4}
\end{array}\right],
$$

where $\mathrm{EC}_{t-1}$ is the error correction term, which is derived from the long-run relationship. The granger causality test may be applied to equation (6) as follows: i) by checking 
statistical significance of the lagged differences of the variables for each vector; this is a measure of short-run causality; and ii) by examining statistical significance of the error-correction terms for the vector that indicates long run causal direction.

\section{Data}

The study uses annual time series data from 1971-2009. The real gross domestic product (GDP) is used as a proxy of economic growth. The physical capital is represented the real gross fixed capital formation, and secondary school enrollment ( $\%$ gross) is used as a skill labor force/human capital. The trade openness index is constructed by using different proxies of trade openness by this study ${ }^{12}$. The data of all variables have been taken from World Bank, world development indicators (online data set).

\section{Results and interpretations}

The available empirical literature indicates that the researchers have used the various proxies like export divided by GDP, import divided by GDP, and export plus import divided by GDP to check the impact of trade openness on economic growth. The benefit of these indicators is that the data are easily accessible, and assumes that a lower value representing the highest degree of policy intervention in trade. The each measure of trade openness captures a different aspect. According to the theoretical literature trade openness is impacting on economic growth by the allocation of resources (Grossman, Helpman 1992). Allowing to this argument, trade openness effects on reallocation of resources according to comparative advantages. Subsequently through the level of export we capture the effect of allocation of resources, thus share of exports in GDP is used as a proxy of trade openness to catch the length of trade openness related to scale economies. The import liberalization is assumed that to endorse the new machinery transfer through import ${ }^{13}$. The import share in GDP is used as a trade openness proxy describing the measurement of openness that is associated to increased international competition. Further the share of the trade (exports and imports) in GDP provides the representation of the technology spillover dimension of trade openness.

By definition all three proxy indicators of trade openness are positively correlated to each other. Thus we cannot use all three trade openness indicators in a single model. If we select any one indicator it is a loss of information. So this study constructs a composite trade openness index (TOI) in case of India. The TOI is developed by calculating the weight of each indicator. The vital weights are calculated by using Principal Component Analysis (PCA). The eigenvalues show that the first principal component demonstrates about $92.8 \%$ cumulative proportion of variation (See Table 1). The second explains another $5.5 \%$ and last principal component demonstrates $1.7 \%$ standardized variation. It

\footnotetext{
${ }^{12}$ These proxies are exports share in GDP $(\mathrm{X} / \mathrm{Y})$, imports share in GDP $(\mathrm{M} / \mathrm{Y})$, and share of the trade (exports pulse imports) in GDP $(\mathrm{X}+\mathrm{M}) / \mathrm{Y}$.

${ }^{13}$ The import of latest machinery is also effected on economic growth through increase in production, then level of export increases and higher inflows of foreign exchange, this is accounted inability to repay the import bill through export earnings.
} 
Table 1. Principal components analysis

\begin{tabular}{|c|c|c|c|c|c|}
\hline \multicolumn{6}{|c|}{ Eigen values: $($ Sum $=3$, Average $=1)$} \\
\hline Number & Value & Difference & Proportion & $\begin{array}{c}\text { Cumulative } \\
\text { value }\end{array}$ & $\begin{array}{l}\text { Cumulative } \\
\text { proportion }\end{array}$ \\
\hline 1 & 2.784 & 2.619 & 0.928 & 2.784 & 0.928 \\
\hline 2 & 0.164 & 0.114 & 0.055 & 2.949 & 0.983 \\
\hline 3 & 0.051 & --- & 0.017 & 3 & 1 \\
\hline \multicolumn{6}{|c|}{ Eigenvectors (loadings): } \\
\hline Variable & PC 1 & PC 2 & PC 3 & & \\
\hline$(\mathrm{X}+\mathrm{M}) / \mathrm{Y}$ & 0.589 & -0.129 & -0.798 & & \\
\hline$(\mathrm{M}) / \mathrm{Y}$ & 0.575 & -0.626 & 0.526 & & \\
\hline$(\mathrm{X}) / \mathrm{Y}$ & 0.568 & 0.769 & 0.294 & & \\
\hline \multicolumn{6}{|c|}{ Correction matrix $^{14}$} \\
\hline & $(\mathrm{X}+\mathrm{M}) / \mathrm{Y}$ & $(\mathrm{M}) / \mathrm{Y}$ & $(\mathrm{X}) / \mathrm{Y}$ & & \\
\hline$(\mathrm{X}+\mathrm{M}) / \mathrm{Y}$ & 1.000 & & & & \\
\hline$(\mathrm{M}) / \mathrm{Y}$ & 0.935 & 1.000 & & & \\
\hline$(\mathrm{X}) / \mathrm{Y}$ & 0.902 & 0.838 & 1.000 & & \\
\hline
\end{tabular}

is lucid first principal component superior than against to the other combination of variables because it shows higher level of variability. So, this study uses the first eigenvector values as a weight to construct a composite measure of trade openness and denoted as TOI. The separately contribution of $(\mathrm{X}+\mathrm{M}) / \mathrm{Y} ;(\mathrm{M}) / \mathrm{Y}$ and $(\mathrm{X}) / \mathrm{Y}$ in standardized variance of the first principal component, i.e. 58.9, 57.5 and 56.8\% respectively.

Figure 1 shows the graph of composite trade openness index (TOI), and indicators of trade openness in the case of India. The TOI moderately increase from 1971 to 1976 and little bit decline in 1977. It shows an increasing trend from 1978 and fluctuates 1985 to 1988, after that it shows increasing and finally sharply decline in 2009.

Table 2 shows the results of Ng-Perron unit root test. The results indicate that all variables are integrated order one.

After determining the level of integration in next step this study investigates the long run relationship by using the autoregressive distributed lag model. The three different scenarios of ARDL model are employed to test the long run connection ${ }^{15}$.

\footnotetext{
${ }^{14}$ The correction matrix indicates that the trade openness indicators are highly correlated each other. So if we include all variables in the same model the problem of multicollinearity exist.

${ }^{15}$ Unrestricted intercept and restricted trend $\left(F_{I V}\right)$, unrestricted intercept and trend $\left(F_{V}\right)$ and unrestricted intercept and no trend $\left(F_{I I}\right)$.
} 


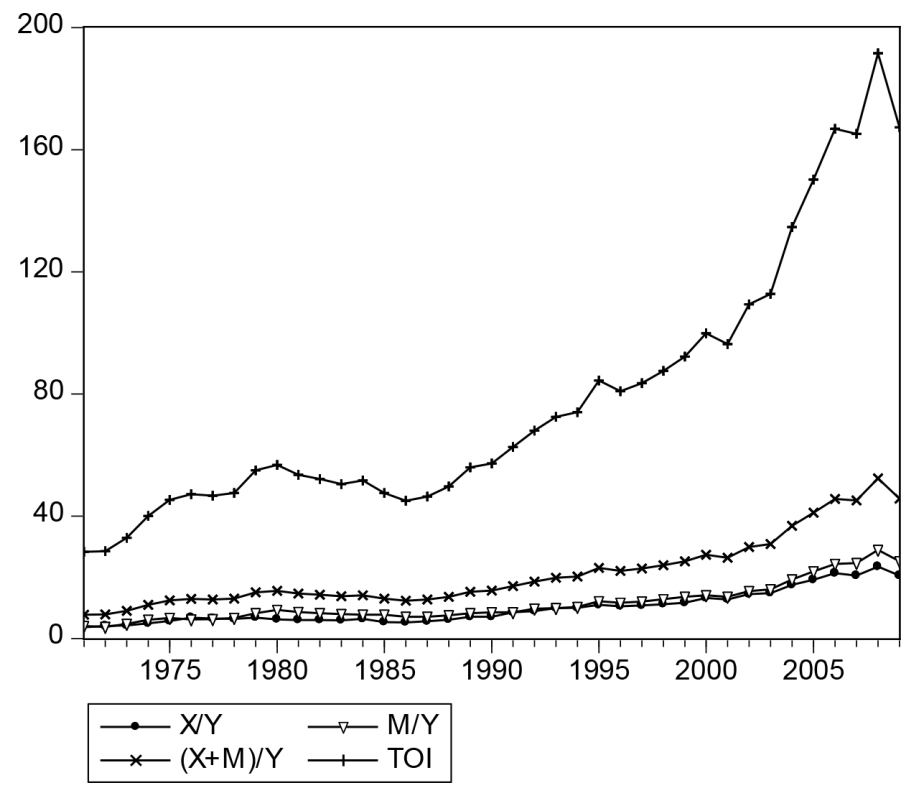

Fig. 1. Trade openness indicators

Source : X, Y and M (obtained from WDI), TOI (author's computations).

Table 2. Unit root test results

\begin{tabular}{lcccc}
\hline Variables & $M Z a$ & $M Z t$ & $M S B$ & $M P T$ \\
\hline At level & & & & \\
\hline Ln(Y) & -1.241 & -0.471 & 0.379 & 35.340 \\
\hline Ln(SL) & -11.267 & -2.371 & 0.211 & 8.096 \\
\hline Ln(K) & -1.284 & -0.507 & 0.395 & 36.912 \\
\hline Ln(TOI) & -9.725 & -2.193 & 0.225 & 9.421 \\
\hline At $1^{\text {st }}$ difference & & & & \\
\hline Ln(Y) & $-17.707^{\mathrm{b}}$ & -2.972 & 0.167 & 5.162 \\
\hline Ln(SL) & $-17.117^{\mathrm{c}}$ & -2.921 & 0.171 & 5.346 \\
\hline $\mathrm{Ln}(\mathrm{K})$ & $-18.133^{\mathrm{b}}$ & -3.001 & 0.165 & 5.084 \\
\hline $\mathrm{Ln}(\mathrm{TOI})$ & $-17.959^{\mathrm{b}}$ & -2.814 & 0.156 & 6.138 \\
\hline
\end{tabular}

Note: b, c respectively indicates the $5 \%$ and $10 \%$ level of significance.

Table 3 shows the critical values of bound test. The Table 4 indicates the result of bound testing analysis. The results suggest the long run relationship between trade openness and economic growth. 
Table 3. Critical values for ARDL modeling approach

\begin{tabular}{lcccccc}
\hline \multirow{2}{*}{$\mathrm{K}=3$} & \multicolumn{3}{c}{0.10} & \multicolumn{2}{c}{0.05} & \multicolumn{2}{c}{0.01} \\
\cline { 2 - 7 } & $I(0)$ & $I(1)$ & $I(0)$ & $I(1)$ & $I(0)$ & $I(1)$ \\
\hline$F_{V}$ & 3.76 & 4.795 & 4.51 & 5.64 & 6.23 & 7.74 \\
\hline$F_{I V}$ & 3.26 & 4.09 & 3.85 & 4.78 & 5.25 & 6.52 \\
\hline$F_{I I I}$ & 2.93 & 4.02 & 3.54 & 4.80 & 5.01 & 6.61 \\
\hline & & & & & & \\
\hline$t_{V}$ & -3.13 & -3.84 & -3.41 & -4.16 & -3.96 & -4.73 \\
\hline$t_{I I I}$ & -2.57 & -3.46 & -2.86 & -3.78 & -3.43 & -4.37 \\
\hline
\end{tabular}

Notes: $\mathrm{k}$ is a number of regressors, $\mathrm{F}_{I V}$ represents the $\mathrm{F}$-statistic of the model with unrestricted intercept and restricted trend, $\mathrm{F}_{V}$ represents the F-statistic of the model with unrestricted intercept and trend, $\mathrm{F}_{I I I}$ represents the F-statistic of the model with unrestricted intercept and no trend. $\mathrm{t}_{V}$ and $\mathrm{t}_{I I I}$ are the $t$ ratios for testing $\alpha_{1}$ in equation (5) is respectively with and without deterministic linear trend. Source: Narayan (2005) for F-statistics and Pesaran et al. (2001) for t-statistic.

Table 4. Bound testing analysis

\begin{tabular}{|c|c|c|c|c|c|c|}
\hline \multirow[b]{2}{*}{ Variables } & \multicolumn{2}{|c|}{$\begin{array}{c}\text { Without } \\
\text { deterministic trends }\end{array}$} & \multicolumn{3}{|c|}{$\begin{array}{c}\text { With } \\
\text { deterministic trends }\end{array}$} & \multirow[b]{2}{*}{ Conclusion } \\
\hline & $F_{I I I}$ & $t_{I I I}$ & $F_{I V}$ & $F_{V}$ & $t_{V}$ & \\
\hline & & & & & & $H_{o}$ \\
\hline \multicolumn{7}{|l|}{$\mathrm{Y}=F[S L, K, T O I]$} \\
\hline & $2.201^{c}$ & $-1.184^{c}$ & $5.603^{a}$ & $4.461^{b}$ & $-3.632^{b}$ & Rejected \\
\hline
\end{tabular}

Notes: $H_{0}$ indicates no cointegration. ' $c$ ' indicates that the statistic lies below the 0.10 lower bound, ' $b$ ' that it falls within the 0.10 bounds and ' $a$ ' that it lies above the 0.10 upper bound. The optimum lag is selected by using the Schwarz Bayesian criterion.

Long run estimated equation

$\operatorname{Ln}(Y)=3.902+0.931 \operatorname{Ln}(K)+0.212 \operatorname{Ln}(S L)-0.301 \operatorname{Ln}(T O I)$

$\begin{array}{llll}\text { (Prob.) } & (0.031) \quad(0.000) & (0.091)\end{array}$

Short run estimated equation

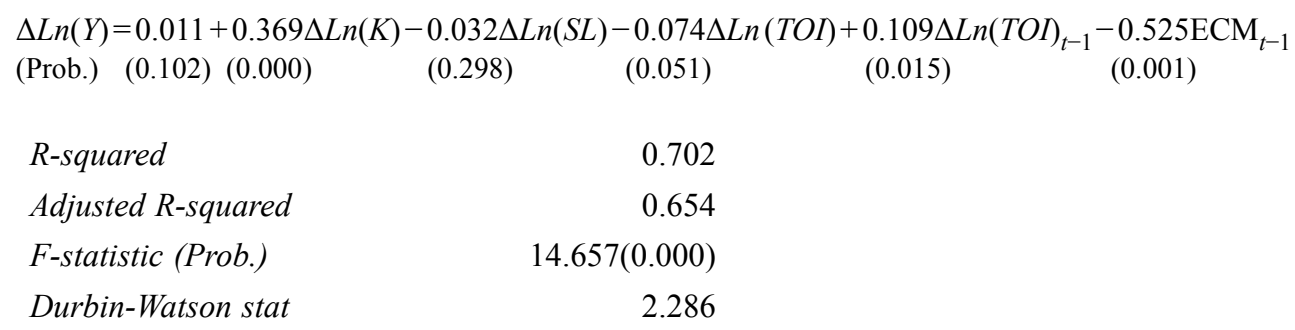


The long run estimated equation indicates that TOI is negatively related to economic growth in the long run. Other things remain constant a one percent increase in Ln(TOI) is associated with a decrease in economic growth by 0.301 percent. This result is supported by the earlier findings of Kim (2011), who found greater trade openness has negatively influenced on both economic growth and real income in the case of less developed countries. Hye (2012), who found a one percent increase in trade openness index causes negatively to economic growth by $0.145-0.368$ percent in case of Pakistan. The empirical result of this study is against the theoretical justification of Romer (1990), and earlier empirical results of Vedpal et al. (2007), Dash (2009), and Marelli et al. (2011) in case of India, and cross country case (Romer 1990; Edwards 1989; Villanueva 1994; Edward 1992; Wacziarg 2001; Ynikkaya 2003). The other economic growth indicators in this investigation i.e. human capital and physical capital both are positively related to economic growth as suggested the new endogenous economic growth theory by Lucas (1988).

The short run estimated equation indicates that trade openness index is positively related to economic growth at one year lag. The error correction term shows the pace of adjustment, where the results indicate that the $52.5 \%$ adjustment in a year from short run disequilibrium to long run equilibrium. The causal relationship is examined by using the modify granger causality test. The results in Table 5 show that the human capital and trade openness index are grangerly caused economic growth in the short run, and also the error correction are negative and significant that confirmed the long run causal relationship from human capital and trade openness to economic growth in the long run. The human capital causes the physical capital in the short run. The causality from trade openness and human capital to economic growth confirms the validity of trade openness-led growth and human capital-led growth in the long run and short run.

\subsection{Rolling window results}

This study also employs the rolling window regression method in order to examine the stability of coefficients by estimating the coefficient of each observation by setting the

Table 5. Granger causality test

\begin{tabular}{lccccc}
\hline & \multicolumn{3}{c}{$\begin{array}{c}\text { Short run causality results } \\
\text { F-statistics }\end{array}$} & $\begin{array}{c}\text { Long run causality } \\
\text { t-statistic }\end{array}$ \\
\hline Variables & $\Delta(\operatorname{Ln}(\mathrm{Y}))$ & $\Delta(\operatorname{Ln}(\mathrm{SL}))$ & $\Delta(\operatorname{Ln}(\mathrm{K}))$ & $\Delta(\operatorname{Ln}(\mathrm{TOI}))$ & $\mathrm{ECM}_{t-1}$ \\
\hline$\Delta(\mathrm{Ln}(\mathrm{Y}))_{-}$ & - & $2.813^{* * *}$ & 0.435 & $2.875^{* * *}$ & $-2.251^{* *}$ \\
\hline$\Delta(\mathrm{Ln}(\mathrm{SL}))$ & 0.007 & - & 0.261 & 1.251 & -1.024 \\
\hline$\Delta(\mathrm{Ln}(\mathrm{K}))$ & 0.512 & $5.264^{* *}$ & - & 1.319 & 0.132 \\
\hline$\Delta(\mathrm{Ln}(\mathrm{TOI}))$ & 0.219 & 0.051 & 0.096 & - & 0.088 \\
\hline
\end{tabular}

Note: $* * * ; * ; *$ respectively $1 \% ; 5 \%$ and $10 \%$ level of significance. 


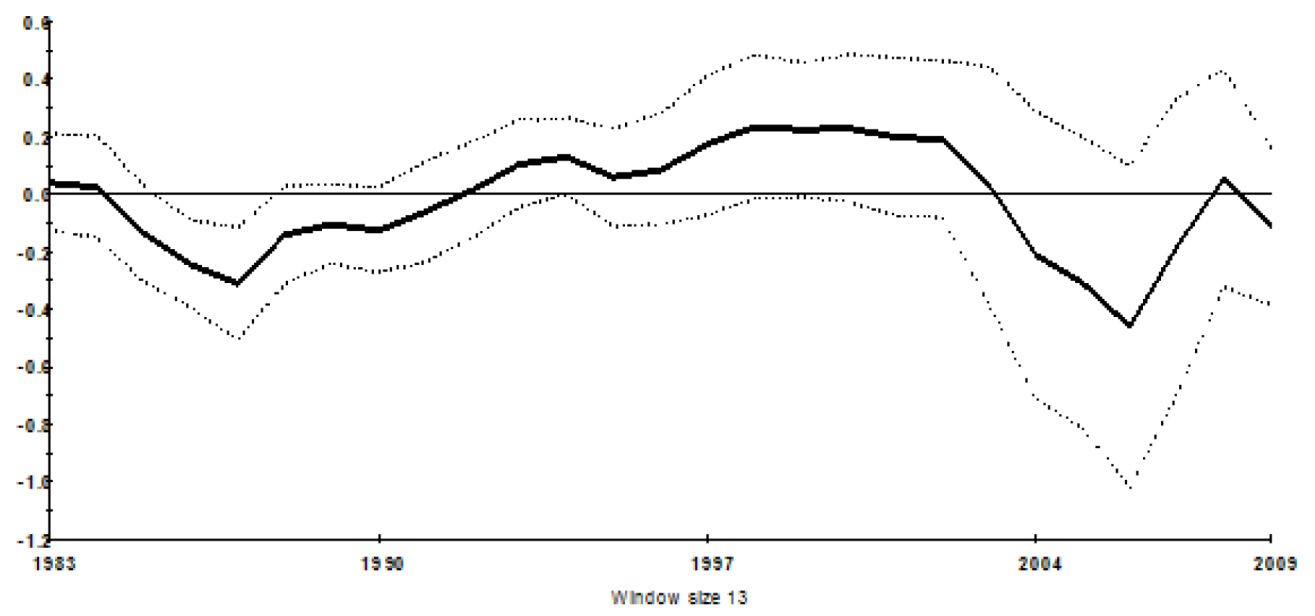

Fig 2. Coefficient of Ln (TOI) and its two* S.E. bands based on rolling OLS Note: dependent variable: $\operatorname{Ln}(\mathrm{Y})$; total no. of regressors: 4.

rolling window size. The Figure 2 shows that trade openness index is negatively associated with economic growth in the years 1985 to 1991 and 2004 to 2009 except 2008. The Indian policy makers have started the trade reforms in the late 1980s and these reforms are showing some continuous positive impact on economic growth from 1992 to 2003. This information is very helpful for Indian policy makers for further formation of trade policies for stable economic growth.

\section{Conclusions}

This study investigates the long run relationship between trade openness and economic growth in the case of India. The available empirical literature indicates that the researchers have used different proxies for trade openness i.e. export divided by GDP, import divided by GDP, and export plus import divided by GDP to determine the effect of trade openness on economic growth. This study contributes to the literature by constructing a composite trade openness index.

The empirical finding shows that trade openness index negatively impacts on economic growth in the long run. This empirical result is supported by Kind (2002), who stated on the basis of theoretical models that full trade liberalization in low income countries can reduce the R\&D incentive as compared to the higher income countries so that imperfect international knowledge spillovers can have a negatively causes to the rate of economic growth, $\operatorname{Kim}$ (2011), who found more trade openness has negatively impacted on both economic growth and real income in the case of less developed countries, and Hye (2012), who found trade openness index negatively causes to economic growth in case of Pakistan. On the other hand, trade openness is positively related to economic growth in the short run. The modify granger causality results suggest that unidirectional 
causal relationship from human capital and trade openness index to economic growth in the long run and short run. These findings are shown the importance of human capitalled growth, and trade openness-led growth hypothesis in the case India for long run economic growth.

The vital evidence is provided by the rolling window regression results i.e. trade openness expedites economic growth continuously only from the years of 1992 to 2003. The present result is equal to the previous findings of Veganzones et al. (1998) in case of Argentina, who found on the basis of a Chow test that the impact of trade openness and foreign technology on economic growth is not stable throughout the century. The empirical findings are very helpful for Indian trade policy makers because the results indicate that in the long run trade openness negatively causes to economic growth, and the rolling window shows that the impact of trade openness on economic growth is not stable throughout the sample. This shows that in the beginning of trade reforms, the Indian policy makers have well managed the trade sector and resulted in some years positive link with economic growth, and also short run impact is positive.

On the basis of empirical results this study is suggesting the following policy implications: there is a need of reallocation of local resources that will increase the exports. The Figure 1 shows that after trade reforms in the year of 2004-2009 the imports of goods and services (\% of GDP) increases larger than as compared to the exports of goods and services (\% of GDP). The rolling regression results show that in these years TOI is negatively linked to economic growth except 2008. Thus there is vital to introduce the trade reforms that will increase economic growth by increase in exports. According to the theory, the skill labor force plays an effective role in the process economic growth, when the GOVT is following the trade openness policies to import the new innovative capital goods from developed countries in order to efficiently utilize the local natural resource. So this is also vital for India to increase expenditure in education sector that will make efficient the abundant factor of labor force.

\section{References}

Aghion, P.; Howitt, P. 1998. Endogenous growth theory. Cambridge: MIT Press.

Ahmed, N. 2003. Trade liberalization and endogenous growth of manufacturing industries in Bangladesh: an empirical investigation, Applied Economics 35(3): 305-314.

http://dx.doi.org/10.1080/713932836

Awokuse, T. O. 2007. Causality between exports, imports, and economic growth: evidence from transition economies, Economics Letters 94(3): 389-395.

Balassa, B. 1985. Exports, policy choices, and economic growth in developing countries after the 1973 oil shock, Journal of Development Economics 4(1): 23-35.

http://dx.doi.org/10.1016/0304-3878(85)90004-5

Barua, A.; Chakraborty, D. 2006. Liberalization, trade and industrial performance: an empirical analysis of India, in APEA conference, 29-30 July 2006, Seattle. 
Batra, R.; Slottje, D. J. 1993. Trade policy and poverty in the United States: theory and evidence, 1947-1990, Review of International Economics 1(3): 189-208.

http://dx.doi.org/10.1111/j.1467-9396.1993.tb00016.x

Bhagwati, J. N. 1978. Foreign trade regimes and economic development: anatomy and consequences of exchange control regimes. National Bureau of Economic Research. Cambridge, MA: Ballinger Publishing Company.

Carmen, M. G.; Pilar, E. 2004. The impact of industry and foreign trade on economic growth in China. An inter-sector econometric model, 1976-2002, Working Paper Series, Economic Development No. 76. Association of Economic Development Studies. University of Santiago de Compostela.

Chuang, Y.-C. 2000. Human capital, exports and economic growth: a causality analysis for Taiwan, 1952-1995, Review of International Economics 8(4):712-720.

http://dx.doi.org/10.1111/1467-9396.00252

Dash, R. K. 2009. Revisited export-led growth hypothesis an empirical study on India, South Asia Economic Journal 10(2): 305-324. http://dx.doi.org/10.1177/139156140901000203

Dutta, D.; Ahmed, N. 2004. Trade liberalization and industrial sector growth in Pakistan: a cointegration analysis, Applied Economics 36(13): 1421-1429.

http://dx.doi.org/10.1080/0003684042000206951

Edwards, S. 1992. Trade orientation, distortions and growth in developing countries, Journal of Development Economics 39(1): 31-57. http://dx.doi.org/10.1016/0304-3878(92)90056-F

Engle, R. F.; Granger, C. W. J. 1987. Co-integration and error correction: representation, estimation, and testing, Econometrica 55(2): 251-276. http://dx.doi.org/10.2307/1913236

Ghatak, S.; Milner, C.; Utkulu, U. 1995. Trade liberalization and endogenous growth: some evidence for Turkey, Economic Planning 28(2-3): 147-167. http://dx.doi.org/10.1007/BF01263635

Greenaway, D.; Nam, C. 1988. Industrialisation and macroeconomic performance, in developing countries under alternative liberalisation scenarios, Kyklos 41(3): 419-435.

http://dx.doi.org/10.1111/j.1467-6435.1988.tb01263.x

Grossman, G. M.; Helpman, E. 1991. Innovation and growth in the global economy. Boston: MIT Press.

Hye, Q. M. A.; Boubaker, H. B. H. 2011. Exports, imports and economic growth: an empirical analysis of Tunisia, The IUP Journal of Monetary Economics 9(1): 6-21.

http://dx.doi.org/10.1007/s11135-011-9612-0

Hye, Q. M. A. 2012. Long term effect of trade openness on economic growth in case of Pakistan, Quality \& Quantity 46(4): 1137-1149. http://dx.doi.org/10.1007/s11135-011-9612-0

Isaksson, A. 2002. Human capital and economic growth: a survey of the empirical literature from 1990 to the present. Mimeo. Vienna: UNIDO.

Khan, M. A.; Qayyum, A. 2007. Trade liberalization, financial development and economic growth, Working Paper 2007:19. Pakistan Institute of Development Economics. Islamabad.

Kim, D.-H. 2011. Trade, growth and income, The Journal of International Trade \& Economic Development: an International and Comparative Review 20(5): 677-709.

Kim, D.-H.; Lin, S.-C.; Suen, Y.-B. 2011. Nonlinearity between trade openness and economic development, Review of Development Economics 15(2):279-292.

http://dx.doi.org/10.1111/j.1467-9361.2011.00608.x

Kind, H. J. 2002. Endogenous growth and trade liberalization between small and large countries, Review of International Economics 10(1): 151-165. http://dx.doi.org/10.1111/1467-9396.00324

Kingsley, O. K.; Okechukwn, O. G.; Adeniyi, A. 2004. Is “trade” openness valid for Nigeria's long-run growth: a cointegration approach? [online], [cited 10 December 2004]. Available from Internet: http://128.118.178.162/eps/it/papers/0412/0412009.pdf 
Leamer, E. E. 1988. Measures of openness, in R. E. Baldwin (Ed.). Trade policy issues and empirical analysis. Chicago: The University of Chicago Press, 147-204.

Lucas, R. E. Jr. 1988. On the mechanics of economic development, Journal of Monetary Economics 22(1): 3-42. http://dx.doi.org/10.1016/0304-3932(88)90168-7

Mankiw, N. G.; Romer, D.; Weil, D. 1992. A contribution to the empirics of economic growth, Quarterly Journal of Economics 107: 407-437. http://dx.doi.org/10.2307/2118477

Marelli, E.; Signorelli, M. 2011. China and India: openness, trade and effects on economic growth, The European Journal of Comparative Economics 8(1): 129-154.

McNab, R. M.; Moore, R. E. 1998. Trade policy, export expansion, human capital and growth, The Journal of International Trade \& Economic Development 7: 237-256.

http://dx.doi.org/10.1080/09638199800000013

Mishra, V.; Sharma, S. S.; Smyth, R. 2010. Is economic development in the pacific island countries export-led or import-led?, Pacific Economic Bulletin 25: 46-63.

Pesaran, M. H.; Shin, Y.; Smith, R. J. 2001. Bounds testing approaches to the analysis of level relationships, Journal of Applied Econometrics 16(3): 289-326. http://dx.doi.org/10.1002/jae.616

Ram, R. 1987. Exports and economic growth in developing countries: evidence from time-series and cross-section data, Economic Development and Cultural Change 36(1): 51-63.

http://dx.doi.org/10.1086/451636

Rivera-Batiz, L. A.; Romer, P. M. 1991. International trade with endogenous technological change, European Economic Review 35(4): 971-1001.

http://dx.doi.org/10.1016/0014-2921(91)90048-N

Rivera-Batiz, F. L. 1995. The economics of technological progress and endogenous growth in open economies. Mimeo: Union College.

Rivera-Batiz, L. A.; Xie, D. 1993. Integration among unequals, Regional Science and Urban Economics 23(3): 337-354. http://dx.doi.org/10.1016/0166-0462(93)90051-F

Romer, P. M. 1989. Growth based on increasing returns due to specialization, American Economic Review 77: 56-62.

Romer, P. M. 1990. The problem of development: a conference of the Institute for the Study of Free Enterprise Systems, Journal of Political Economy 98(1): 1-11.

Salvatore, D.; Hatcher, T. 1991. Inward oriented and outward oriented trade strategies, Journal of Development Studies 27(3): 7-25. http://dx.doi.org/10.1080/00220389108422201

Shahbaz, M.; Azim, P.; Ahmad, K. 2011. Exports-led growth hypothesis in Pakistan: further evidence, Asian Economic and Financial Review 1(3): 182-197.

Söderbom, M.; Teal, F. 2001. Trade and human capital as determinants of growth, CSAE Working Paper 2001.10. Oxford.

Sonmez, F. D.; Sener, P. 2009. Effects of human capital and openness on economic growth of developed and developing countries: a panel data analysis, International Journal of Social and Human Sciences 3: 633-637.

Soukiazis, E.; Antunes, M. 2012. Foreign trade, human capital and economic growth: an empirical approach for the European Union countries, Journal of International Trade \& Economic Development 21(1): 3-24. http://dx.doi.org/10.1080/09638199.2012.643013

Topalova, P. 2004. Trade liberalization and firm productivity: the case of India, IMF Working Paper WP/04/28. Asia and Pacific Department, International Monetary Fund, Washington, DC.

Turnvosky, S. 2001. Growth in an open economy: some recent developments, in J. Smets, M. Dombrecht (Eds.). How to promote economic growth in the Euro Area. Cheltenham: Edward Elgar. 
Vamvakidis, A. 2002. How robust is the growth openness connection? Historical evidence, Journal of Economic Growth 7: 177-194. http://dx.doi.org/10.1023/A:1013418610712

Ved, P.; Sudesh, P. 2007. An empirical investigation of the causal relationship between openness and economic growth in India, Asian Economic Review 49(3): 485-494.

Véganzonès, M.-A.; Winograd, C. 1998. Human capital, trade openness and growth in Argentina in the 20th century, Labour: 305-352. http://dx.doi.org/10.1111/1467-9914.00070

Villanueva, D. 1994. Openness, human development and fiscal policies, IMF Staff Papers 41: 1-29. http://dx.doi.org/10.2307/3867483

Wacziarg, R. 2001. Measuring the dynamic gains from trade, The World Bank Economic Review 15(1): 393-429. http://dx.doi.org/10.1093/wber/15.3.393

Yanikkaya, H. 2003. Trade openness and economic growth: a cross country empirical investigation, Journal of Development Economics 72(1): 57-89.

http://dx.doi.org/10.1016/S0304-3878(03)00068-3

Young, A. 1991. Learning by doing and the dynamic effects of international trade, Quarterly Journal of Economics 106(2): 369-406. http://dx.doi.org/10.2307/2937942

Qazi Muhammad Adnan HYE, M. Phil in Economics, PhD student at the University of Malaya, Faculty of Economics and Administration. The research interests are liberalization policies and macroeconomic modeling. He is the author of articles in various journals: Quality \& Quantity-International Journal of Methodology, Journal of Risk Finance, Chinese Management Studies, China Agricultural Economic Review, Journal of Chinese Economic and Foreign Trade Studies, Asia Pacific Journal of Tourism Research, International Journal of Economic Perspectives, Banking and Finance Letters, The Asian Economic Review, and other journals. He is the editor of Asian Economic and Financial Review published by Asian Economic and Social Society.

Wee-Yeap, LAU is currently the Head, Department of Applied Statistics at Faculty of Economics \& Administration, University of Malaya. He has been a visiting Scholar at Risk Management Institute National University of Singapore. He completed both his PhD and Master of Economics at Osaka University under the Monbusho Scholarship from Ministry of Education in Japan. 